\title{
Access to Safe Water Among Waterfront Dwellers in Port Harcourt Metropolis, South-South Nigeria
}

\author{
Idoniboyeobu, Frances Opubo, \\ Ekenedo, Golda. O. PhD,
}

Department of Human Kinetics and Health Education

Faculty of Education University of Port Harcourt

Doi:10.19044/esj.2020.v16n12p283 URL:http://dx.doi.org/10.19044/esj.2020.v16n12p283

\begin{abstract}
The study examined access to safe water among waterfront dwellers in Port Harcourt Metropolis, Nigeria. The study further established effects of some demographic variables on access to safe water. A descriptive, crosssectional study was carried out among a population of 337,489 waterfront dwellers of the 40 waterfronts in Port Harcourt Metropolis using a sample of 1400 waterfront dwellers drawn through a multi-stage sampling procedure. Instrument used for data collection was 11-item structured questionnaire titled "Access to Safe Water Questionnaire" (ATSWQ) which has a reliability index of 0.97 and focus group discussion. Data collected was analysed using the Statistical package for Social Sciences (SPSS) version 10. Descriptive statistic of Mean was used to establish access to safe water while inferential statistic of Analysis of Variance (ANOVA) set at 0.05 level of significance was employed to determine the effects of demographic variables on access to safe water. The findings of the study revealed that waterfront dwellers in Port Harcourt Metropolis did not have access to safe water $(\overline{\mathbf{X}}=1.01<2.0)$. Whereas significant difference existed in access to safe water among the waterfront dwellers based on educational status and family size $(P=0.00$ respectively), the contrary was the case in respect of marital status $(P=0.89)$. The study concluded that the waterfront dwellers were at serious risk of waterborne diseases and required immediate intervention especially health education intervention.
\end{abstract}

Keywords: Safe Water, Access, Demographic Variables, Waterfronts

\section{Introduction}

Water is one of the most basic of human needs, it is crucial in sustaining every aspect of human endeavour. Though water covers over 97\% of the Earth's surface, only 3\% is regarded as safe water (Dangana, Halilu, 
Asiribo-Sallau \& Kuta, 2015). Unfortunately, it has been found that globally, 3 in 10 persons, or 2.1 billion people, lack access to safe water (World Health Organization - WHO \& United Nations International Children's Emergency Fund - UNICEF, 2017). This population is predominantly in developing countries; a situation aggravated by population growth, urbanization and increased domestic and industrial water use (Ganio, et al. 2011).

Safe water means water that will not cause any harm to the body if it comes in contact with it (WHO \& UNICEF, 2012). It is water that is free from contamination (World Bank, 2016). The most common use of the term safe water applies to drinking water by majority of people, but it could also apply to water for bathing, washing and cooking (Glasgow, 2009). Water can become unsafe either from the water source or through handling and storage. Such water can be made safe through various forms of treatment. For instance water from such sources as shallow wells and rivers are usually not safe except when they are treated. Safe water, therefore, shall be referred to herein as a type of water that is safe for human consumption and use; it includes pipe borne water, treated borehole water, treated well water, treated water from the river, treated stream water, treated pond water and treated rain water.

Unsafe water on the other hand is water that is contaminated with germs, worms, or toxic chemicals and not fit for use and as such can cause serious illnesses. According to WHO and UNICEF (2010), unsafe water is water gotten from unprotected wells and springs, rivers, ponds and water from vendors. Water can come clean from the source but rendered unsafe through handling. Hence, rain water for instance; may be safe from source but can be rendered unsafe by unhygienic collection and storage methods. Therefore, unsafe water in this paper shall refer to untreated borehole water, well, river, stream, pond and rain water.

Waterfront is that part of a town next to the sea or river or other water bodies (Hornby, 2000). In most developed countries waterfront is usually a beautifully developed and reserved area used mainly for recreation, relaxation and habitation. Ironically, waterfronts of many developing countries are slums. They are usually occupied illegally by low class people who cannot afford decent accommodation in the city. Living structures there are usually makeshift and living conditions deplorable, devoid of government presence. In Nigeria, government is always attempting, most times without success, to evict dwellers of waterfronts in their bid to put the waterfronts to a more befitting use.

Poor access to improved water and sanitation in Nigeria remains a major contributing factor to high morbidity and mortality rates among children under five. The use of contaminated drinking water and poor sanitary conditions result in increased vulnerability to water-borne diseases, including 
diarrhoea (Haryanto \& Sutomo, 2012) which leads to deaths of more than 70,000 children under five annually (UNICEF, 2018).

Access to safe water is a human right issue, and ensuring access to safe water could reduce the global burden of disease (Corcoran, Nellemann, Baker, Bos, \& Osborn, 2010). The United Nations General Assembly declared that safe and clean drinking water should be accessible and affordable and is essential for the full enjoyment of life (United Nations, 2010). But this has not been achieved in developing Countries including Nigeria. Though, Nigeria as a country is abundantly blessed with water resources, however, as at 2015, only $19 \%$ of Nigeria's population has access to safe drinking water (The Conservation, 2017). Hence, most of the population lack access to safe drinking water, greater majority of which are of rural population and in the waterfronts (Umezulike, 2017). One of the major reasons for lack of safe water in Nigeria especially in riverine areas like Rivers State is pollution. People commonly defecate and empty refuse into the river and drainages. In addition, oil spillage in the Niger Delta region where oil exploration takes place contributes to the problem by contaminating sources of water (Conservation, 2017).

Despite the strong clear evidence that providing safer, accessible and more reliable supplies of water can lead to a healthier population and economy of a country, millions of people in Nigeria and in the waterfronts are still struggling to access safe water while many people are dying each year from the use of unsafe water, poor sanitation and hygiene (WHO (2017). According to WHO and UNICEF (2017) Joint Monitoring Programme, Nigeria ranked $165^{\text {th }}$ position among populations with access to improved water source. The lack of accessible, reliable and safe drinking water, together with poor sanitation and hygiene, is estimated to cost Nigeria about USD \$1.3 billion in access time, loss due to premature death, productive time lost and health care costs (The Conservation, 2017).

Rivers state as the name implies is located in the coastal region of Nigeria which explains the existence of 40 waterfronts in Port Harcourt Metropolis alone. It is one of the Niger Delta States where major oil explorations take place. Port Harcourt metropolis is made up of three Local Government Areas namely, Port Harcourt, Obio/Akpor and Ikwerre. Dwellers of waterfronts are basically squatters occupying illegal lands and consequently hardly benefit basic amenities from the Governments of the state. Over the last 50 years, the population of Port Harcourt has increased from 56,000 inhabitants in 1950 to more than 1.1 million in 2010, and is projected to reach 1.68 million in 2025 (UN-HABITAT 2009). The population growth in the city has resulted in expansion of slum settlements characterised by poor water distribution and poor waste disposal. 
Financial status influences access to safe water. About $80 \%$ of wealthy Nigerians have access to at least a basic water supply, in comparison to only $48 \%$ of poor Nigerians (The Conservation, 2017). The waterfronts are characterized by dense population, poverty, make-shift buildings, lack of basic amenities such as pipe-borne water, modern toilet facilities, and lack of basic personal and environmental hygiene, access roads, and security. Because of lack of support from the government and other Non-governmental Organizations, the dwellers of the waterfronts had to source for water themselves which may not be safe for use.

Some demographic factors can play some role in the level of access to safe water among the waterfront dwellers. For instance, educational status, especially of the household head has been found to determine the household's water sourcing behaviour (Onundi \& Ashaolu, 2014). Level of education is believed to play an important role in understanding how safe water can be and the measures taken to treat water gotten from unimproved sources. So household with more educated people tend to differentiate safe and unsafe water than those with primary or no formal education who do not really care about how safe water might be (Onundi \& Ashaolu, 2014). Again, where the number of persons in each household is more than the income of the household head, the family will not be able to generate enough money to get water for family use (Totouom \& Fondo, 2012) and this compels the members of household to use water from unimproved sources.

The aim of the study therefore was to determine access to safe water among the waterfront dwellers in Port Harcourt Metropolis. A further aim of the study was to establish if there were differences in access to safe water based on demographic variables of marital status, educational status and family size.

\section{Methods}

The study adopted the descriptive cross-sectional survey design. The population for the study comprised 337,489 individuals living in 40 waterfronts in Port Harcourt Metropolis (National Population Commission, 2019). A total of 1400 waterfront dwellers constituted the sample size for the study. The first stage of the sampling procedure involved the selection of 12 waterfronts from the existing 40 using systematic sampling procedure. Then 120 households were selected from each of the sampled waterfronts. An adult member of each selected household that gave consent was recruited as a respondent.

Data was collected using 11-item questionnaire titled "Access to Safe Water Questionnaire" (ATSWQ) and focus group discussion. The questionnaire is a 3-point scale of highly accessible (HA), occasionally accessible (OA) and not accessible (NA). Face and content validity of the 
instrument was established through the scrutiny of three (3) experts. The reliability of the instrument was ensured through a test re-test which yielded a coefficient of 0.97 using the Pearson Product Moment Coefficient Correlation. Focus group discussion session was done in four (4) waterfronts. There were two female groups and two male groups. Each of the groups comprised 6 participants. The leader and clerk of each group were selected from among the participants and trained briefly on how to conduct the discussion. The recorded discussions were transcribed and used for discussion of findings.

Data analyses was done using mean and Analysis of Variance (ANOVA) set at 0.05 level of significance. A criterion mean of 2.0 was used to decide access to safe water whereby a mean score of 2.0 and above was regarded as having access to safe water and mean score that is below 2.0 indicated lack of access to safe water.

\section{Results}

Table 1: Summary of mean rating of access to safe water among waterfront dwellers in Port Harcourt

\begin{tabular}{ccccc}
\hline S/N & Access to safe water & $\overline{\mathbf{X}}$ & SD & Decision \\
\hline & Access to safe water for drinking & $\mathbf{1 . 0 4}^{*}$ & $\mathbf{0 . 0 8}$ & No access \\
Access to safe water for washing & $\mathbf{1 . 0 0}^{*}$ & $\mathbf{0 . 0 5}$ & No access \\
Access to safe water for bathing & $\mathbf{1 . 0 0}^{*}$ & $\mathbf{0 . 0 5}$ & No access \\
Access to safe water for cooking & $\mathbf{1 . 0 0}^{*}$ & $\mathbf{0 . 0 3}$ & No access \\
Grand Mean & $\mathbf{1 . 0 1}^{*}$ & $\mathbf{0 . 0 4}$ & No access \\
\hline
\end{tabular}

The result showed that access to safe water among waterfront dwellers in Port Harcourt metropolis was below average with a grand mean of 1.01, $\mathrm{SD}=0.04$. The respondents mainly indicated that safe water supply was not assessable for drinking, washing, bathing and cooking at the waterfronts.

Table 2: Summary of One-Way Analysis of Variance on access to safe water among the waterfront dwellers based on marital status, educational status and family size

\begin{tabular}{|c|c|c|c|c|c|c|c|}
\hline Demographics & Source & $\begin{array}{c}\text { Sum of } \\
\text { Squares }\end{array}$ & Df & $\begin{array}{c}\text { Mean } \\
\text { Square }\end{array}$ & $\mathbf{F}$ & Sig. & Decision \\
\hline \multirow[t]{3}{*}{ Marital Status } & Between & .012 & 3 & .004 & 2.181 & .089 & Not significant \\
\hline & Within Groups & 2.376 & 1348 & .002 & & & \\
\hline & Total & 2.388 & 1351 & & & & \\
\hline \multirow[t]{3}{*}{$\begin{array}{l}\text { Educational } \\
\text { status }\end{array}$} & $\begin{array}{c}\text { Between } \\
\text { Groups }\end{array}$ & .044 & 3 & .015 & 8.376 & .000 & Significant \\
\hline & Within Groups & 2.344 & 1348 & .002 & & & \\
\hline & Total & 2.388 & 1351 & & & & \\
\hline \multirow[t]{3}{*}{ Family size } & $\begin{array}{c}\text { Between } \\
\text { Groups }\end{array}$ & .046 & 2 & .023 & 13.328 & .000 & Significant \\
\hline & Within Groups & 2.341 & 1349 & .002 & & & \\
\hline & Total & 2.388 & 1351 & & & & \\
\hline
\end{tabular}


There were significant differences in access to safe water among the waterfront dwellers based on educational status $\left(\mathrm{F}_{3}, 1348=8.376, \mathrm{p}<.05\right)$ and family size $\left(\mathrm{F}_{2}, \quad 1349=13.328, \mathrm{p}<.05\right)$ whereas there was no significant difference in access to safe water among the waterfront dwellers based on marital status $\left(\mathrm{F}_{3}, 1348=2.1881, \mathrm{p}>.05\right)$.

\section{Discussion}

The findings of the study showed that access to safe water among waterfront dwellers in Port Harcourt metropolis was below average with an overall grand mean of 1.01 and SD of 0.04 . The participants indicated lack of access to safe water in the four basic areas of need namely drinking, cooking, washing and bathing. These findings are consistent with an earlier finding by Belstine, (2016) which revealed that majority of the households in urban slums of Kolkata, India lacked access to safe water. Port Harcourt waterfronts as earlier explained are comparable to urban slums sharing similar characteristics such as dense population, poverty, make-shift buildings, lack of basic amenities such as pipe-borne water, modern toilet facilities, and lack of basic personal and environmental hygiene, access roads, and security. It also confirms the assertions of Magombo \& Mphangwe-Kosamu, (2016) and Akhie \& Ahmed, (2018) that the problem of lack of access to safe water is common among developing countries including Nigeria.

The finding of this study though expected is unfortunate. It is expected because literature has shown that pollution, oil spillage, poverty, poor sanitation and lack of government presence which are basic characteristics of waterfronts in Nigeria are factors associated with unsafe water. Focus group discussants said that their major sources of water at the waterfronts were borehole, well and rain water. These sources should ordinarily be regarded as safe sources of water, but in this case they are not because of the poor hygiene and sanitation practices surrounding the borehole environment and the unhygienic handling of the water. As a matter of fact it was observed that most water storage containers in the areas lack adequate covers and kept outside the houses thereby putting them at risk of contamination. The focus group discussions also indicated that the boreholes at the waterfronts were not enough to serve the people. One of the participants from 'Ojike' waterfront said " how can we claim to have safe water, when we have only one borehole here, is it by magic" The condition of living in the waterfronts in Port Harcourt is generally poor. The houses are shanties and overcrowded.

The finding is unfortunate because this is happening in $21^{\text {st }}$ Century, in a country that is rich in oil and human resources, and in a city that prides itself as the treasure base of the nation; a city that hosts all the oil companies in Nigeria. The inhabitants deserve better conditions of living especially clean and safe water. The implication of this finding is quite obvious. Inhabitants of 
waterfronts in Port Harcourt metropolis especially children are at extreme risk of water-borne diseases as posited by Haryanto and Sutomo (2012). They are also in dire need of intervention especially in the area of health education to equip them with knowledge and basic skills in water purification.

The study shows that the singles, married, divorced and the widowed that live at the waterfronts all lack access to safe water. It was expected at least that those who were single would have less problem accessing safe water because they have only themselves to cater for and therefore will be ready to go the extra mile to access safe water. However, that was not the case, showing that the problem is a perennial one. This finding is contrary to the finding of Angoua, Dongo, Templeton, Zinsstag \& Bonfoh, (2018) that marital status was a key factor in access to safe water.

On the other hand, the study recorded a significant difference in access to safe water among the waterfront dwellers based on educational status as access to safe water was higher among those with secondary education and above. Angoua, Dongo, Templeton, Zinsstag \& Bonfoh, (2018) found that educational level of the respondents was associated with access to safe water in poor peri-urban settlements of Abidjan, Côte d'Ivoire. Logically, education increases people's hygiene consciousness and practices; so this finding which shows that those with higher educational status had more access to safe water is in order.

The study revealed significant difference in access to safe water based on the size of family. According to the finding, lack of access to safe water at the waterfronts was more with households that had a family size of 10 and above. Also, participants from the four waterfronts opined that large family size hinder their access to safe water as it is difficult for the household heads to provide safe water that will be enough to serve the entire members of the households, since the owners of the few boreholes at the waterfronts use their generators to pump the water and sell at a high price. So those who could not afford tend to source for a cheaper and unsafe sources exposing their families to risk of diseases. Slums like waterfronts in developing countries are characterized by over population and overcrowding which are clear evidence of poverty and low literacy level. These factors which are linked altogether ensure lack of access to safe water among this population.

\section{Conclusion}

Based on the findings of the study, the researchers concluded that waterfront dwellers in Port Harcourt Metropolis, Nigeria were at serious risk of water-borne diseases due to established lack of access to safe water among them and, therefore, required immediate intervention. 


\section{Recommendations}

Based on the findings and conclusion of the study, the following recommendations were made:

1. Government in collaboration with non-governmental organizations and private individuals should embark on water projects such as sinking of boreholes that will be enough to serve the waterfront dwellers and providing support in ensuring that existing boreholes are treated.

2. The waterfront dwellers should be educated on proper storage and inexpensive methods of purifying water to avoid contamination of the water and prevent diseases emanating from the use of unsafe water.

3. Family planning efforts should be intensified at the waterfronts as an attempt to reduce family size and increase opportunities of accessing safe water by households.

4. School curriculum at all levels of education should be reviewed with a view to ensure that all important and current information about water safety is covered.

\section{References:}

1. Akhie, A. A., \& Ahmed, A. (2018). Water Supply and Sanitation Scarcity Assessment of Urban Slum: A Comprehensive Case Study for Mirpur. Proceedings of the 1st National Conference on Water Resources Engineering Chittagong, Bangladesh.

2. Angoua, E., L, Dongo, K., Templeton, M., R, Zinsstag J \& Bonfoh, B. (2018). Barriers to access improved water and sanitation in poor periurban settlements of Abidjan, Côte d'Ivoire. Journal of Public Medical Institute. 13(8):1.

3. Belstine, H., A. (2016). Understanding the barriers of clean water access in urban slums of Kolkata, India. Journal for Global Health, $3(1): 46-56$.

4. Corcoran, E., C. Nellemann, E., Baker, R., Bos, D \& Osborn, H., S. (2010). Sick water: The central role of waste-water management in sustainable development. A rapid response assessment. United Nations Environment Programme, UN-HABITAT, GRID-Arendal. www.grida.ng.

5. Dangana, K., Halilu, P., H, Asiribo-Sallau, O., R \& Kuta, G., I. (2015). Dimensions of water accessibility in the Southern Part of Niger State. Nigerian Journal of Natural Sciences Research. 5(12): 2224-3186.

6. Ganio, M., S, Armstrong, L., E, Casa, D., J, McDermott, B., P, Lee, E., C, Yamamoto, L., M, Marzano, S., Lopez, R., M, Jimenez, L., Le Bellego, L., Chevillotte ,E \& Lieberman, H., R. (2011). Mild 
dehydration impairs cognitive performance and mood of men. British Journal of Nutrition. 106(10): 35-43.

7. Glasgow, R., D, V. (2009). The concept of water. United Kingdom. Chapter 1. Origin 1.

8. Hornby, A., S. (2000). Definition of waterfront. Oxford advanced learners dictionary of current english. Oxford university press in the United Kingdom. 6th Edition.

9. Magombo, P. U., \& Mphangwe-Kosamu, I. B. (2016). Challenges of water accessibility in the urban centres of Malawi: A case study of Blantyre City. African Journal of Environmental Science and Technology, 10(10): 380-385.

10. National Population Commission (NPC), (2019). Official results of National Population and Housing Census.

11. Onundi, F., T \& Ashaolu, E., D. (2014). A look into household's water use behaviour in Irepodun Local Government Area of Kwara State, Nigeria, Journal of Environment and Earth Science. 4 (2). Available at www.iiste.org.

12. The Conversation (2017). How Nigeria is wasting its rich water resources. Accessed on January 19, 2019 from http://theconversation.com/how-nigeria-is-wasting-its-rich-waterresources- 83110

13. Totouom, F. L. A \& Fondo, S. (2012). Determinants of the households' choice of drinking water source, Cameroon. Journal of Sustainable Development in Africa 14(3): 86-97.

14. Umezulike, C. (2017). Challenges in the Nigerian water sector - If the problem is not lack of comprehensive regimes, then what is it? Available online: http://www.connecteddevelopment.org.

15. Unicef, (2018). Water, sanitation and hygiene. Accessed on January 19, 2019 from https://www.unicef.org/nigeria/water-sanitation-andhygiene

16. United Nations, (2010). Resolution on the human right to water and sanitation. In: Sixty-fourth Session of the United Nations General Assembly, New York. Article 48: 64/292. http://www.un.org/waterforlifedecade/human_right_to_water.shtml

17. World Bank, (2016). World leaders call for action on water. Press release, world water council.http://www.worldbank.org/en/news/pressrelease/2016/09/21/world-leaders-call-for-action-on-water.

18. World Health Organization, (2017). Fact sheet 7 on water, sanitation and hygiene: Transforming the regional agenda towards equitable access to safe and sustainable services. Sixth Ministerial Conference on Environment and Health. 
19. World Health Organization (WHO) \& United Nations International Children's Emergency Fund (UNICEF) (2010). Progress on Sanitation and Drinking-water. Update, on WHO/UNICEF Joint Monitoring Programme for Water Supply and Sanitation Geneva, Switzerland.

20. World Health Organization (WHO) \& United Nations International Children's Emergency Fund (UNICEF) (2012). Joint Monitoring Programme (JMP) for Water Supply and Sanitation. http://www.wssinfo.org/

21. World Health Organization (WHO) \& United Nations International Children's Emergency Fund (UNICEF) (2017). Progress report on Drinking Water, Sanitation and Hygiene. Update and SDG Baselines. Geneva. 